\title{
COM \\ Revisiting public debate on Genetic Modification and Genetically Modified Organisms. Explanations for contemporary Dutch public attitudes
}

\section{Lucien Hanssen, Anne M. Dijkstra, Susanne Sleenhoff, Lynn J. Frewer and Jan M. Gutteling}

Abstract

Keywords

DOI

Introduction
Genetic Modification (GM) has been a topic of public debates during the 1990s and 2000s. In this paper we explore the relative importance of two hypothesized explanations for these controversies: (i) people's general attitude toward science and technology and (ii) their trust in governance, in GM actors, and in GM regulations, in explaining the Dutch public's Attitude toward GM applications, and in addition to that, the public's GM Information seeking behaviour. This will be conducted through the application of representative survey methodology. The results indicate that Attitudes toward GM applications are best predicted by both the attitude toward science and technology and three trust measures. GM information seeking is predicted by gender and educational level, as well as attitude toward science and technology, trust in organisations and trust in regulations (negative). Overall, psychological variables seem better predictors than demographics. Implications for future research on information seeking behaviour are discussed.

Public perception of science and technology; Risk communication; Science communication: theory and models

https://doi.org/10.22323/2.17040201
Genetic Modification (GM) and Genetically Modified Organisms (GMOs) have been a topic of many public debates during the 1990s and 2000s in Europe in general, and the Netherlands specifically [Durant, Bauer and Gaskell, 1998; Bauer and Gaskell, 2001; Gutteling et al., 2006]. Studies such as the Eurobarometer surveys, which have been conducted periodically since the early 1990s, have shown negative public attitudes toward GM and GMOs in most countries in Europe [Gaskell et al., 2010]. The latest comparative quantitative European study that included Dutch attitudes, again a Eurobarometer-survey, dates from 2010 and showed that around $30 \%$ of the Dutch population was in favour of applications of GM in food, while, in contrast, medical applications of GM were supported by $70 \%$ of the Dutch population [Eurobarometer, 2010]. 
Based on new unpublished data, this paper focuses on developing new explanations for contemporary public attitudes toward GM and GM applications which have become an issue of considerable interest in the scientific literature. Previously, research has suggested that individuals with more positive or negative attitudes toward science and technology are associated with more positive or negative attitudes toward GM [e.g. Cormick and Romanach, 2014]. For instance, Kahan et al. [2009] have found support for nanotechnology, particularly among people with a pro-technology cultural orientation, when they were exposed to information about nanotechnology. Earlier survey research in the United States and Europe has showed that attitudes toward nanotechnology are determined by cultural value differences in the appreciation of technological innovations [Gaskell et al., 2005]. Several authors have pointed out the relationship between attitudes and the public's trust in businesses, public agencies, governments or public interest groups is an important determinant of attitudes. All of these interest groups potentially communicate about biotechnology to promote different perspectives or vested interests [e.g. Landrum et al., 2018; Marques, Critchley and Walshe, 2015; Post and Maier, 2016].

In addition to public attitudes, we also focus on an individual's information seeking behaviour. Information is an important component in formation of attitudes in societal dilemmas such as the use of genetic modification technologies [Jennings, 2018; Vugt, 2009]. Over the last 20 years, the information landscape has changed considerably, from a delivery-dependent population (e.g. mass media, or governmental campaigns providing general information) to a situation where many people actively and continuously search for information which is of personal interest on social media [Rutsaert et al., 2013; Rutsaert et al., 2014; Van Dijck, Poell and De Waal, 2016].

In this paper, we will explore the relative importance of two explanations of the Dutch public's Attitude toward GM applications and their GM Information seeking behaviour. Specifically these will assess the relationship between people's 'Attitudes toward science and technology', and their 'Trust in governance organizations with responsibility for regulating GM'. These two issues will be explored through the application of representative survey methodologies.

\section{Theoretical perspectives}

\section{Developments in genetic modification}

Biotechnology has been developing rapidly since the emergence of recombinant DNA technologies in the 1990s. Today digitization and robotization of laboratory processes has resulted in the science of genetic modification becoming more precise and accessible to potential users, as well as being cheaper in terms of development costs. Improved reading and analysing of DNA, together with the application of new genome editing techniques such as CRISPR-Cas systems, has made it possible to genetically modify organisms precisely and quickly [Sander and Joung, 2014; Kim and Kim, 2014]. A question arises as to whether society will accept the application and consequences of such rapid technological advances. The public image of biotechnology may not have changed since the 1990s. Specific cases of DNA technology applications have attracted media and stakeholder attention and societal discussion, for example Dolly the sheep, the Human Genome Project or Golden Rice. However, it is arguable that few outside the biotechnology "inner circle" are aware of the radical changes that have taken, and continue to take, place 
in terms of scientific advances [Reardon, 2016; Editorial, 2016]. There is also an observable difference in implementation of GM technologies between the EU and the rest of the world, in particular in relation to GM crops [Cyranoski, 2010; Lucht, 2015]. For example, in recent years the planting of new GM crops has increased in North and Latin America, as well as in Asia, while planting has decreased in Europe [James, 2016].

At the same time, it has been observed that the distinction between new breeding techniques and conventional types of crop breeding are no longer as delineated as before [COGEM, 2016; Border and Walker, 2017]. When applied to plants, these new techniques enable faster, more precise and more directed results than is possible using conventional breeding techniques. These new methods provide opportunities that enable responses to societal challenges, such as the development of more sustainable agricultural practices, combatting climate change, and the transition toward a sustainable bio-based economy. New gene-editing tools also open new possibilities in relation to the modification of the genome of animals with the potential to enhance productivity or disease resistance in major livestock species, and to produce medicines or human organs for transplantation [COGEM, 2016; Border and Dawson, 2016]. As well as delivering intentioned benefits, these developments raise important questions regarding governance as well as societal and ethical concerns [Frewer et al., 2013; COGEM, 2016; Border and Dawson, 2016]. In addition, there is the dilemma of rising public awareness in an inclusive, transparent and responsible manner [Cooke and Kothari, 2001; Irwin, 2014; Hanssen, 2009; Leyser, 2014]. Consequently, it is not clear how public attitudes toward early genetic modification and contemporary genome editing and its applications will develop, change and crystallise as novel applications come "on stream" [Kronberger, Wagner and Nagata, 2014; Nerlich and McLeod, 2016; Rousselière and Rousselière, 2017].

In the section below, we outline a short theoretical context for the two dependent variables in our study: the Dutch public's Attitude toward GM applications, and their GM Information seeking behaviour.

\section{Attitude toward GM applications}

Dutch public protests were triggered by the arrival of imported GM maize into Rotterdam in the Autumn of 1996 [Van der Veer et al., 2001], and with Dolly the cloned sheep, which was introduced in February 1997 [Einsiedel et al., 2002]. The media coverage of GM foods increased considerably [e.g. see, inter alia, Bauer et al., 2001; Frewer, Miles and Marsh, 2002]. At the same time, non-governmental organizations (NGOs) opposing GMOs increased their profile and activities in Europe, with their campaigns being taken up and multiplied by media attention. Frewer et al. [2013] reviewed 70 empirical articles through a meta-analysis of perceptions of GM for food applications. The results indicate that both perception of risks and benefits of GM food applications increased over the years. Generally speaking, the results suggest that Europeans perceive more risks than people from the U.S. or Asia. However, ethical and moral objections were stronger in the U.S. than in Europe.

Gaskell et al. [2004] started from the premise that some stakeholders believed that the societal resistance to GM food was primarily due to a "biased" risk perception 
of the public, which could be corrected through "accurate" information provision by trusted sources. However, according to Gaskell and co-authors, this strategy assumed that the benefits of GM food will be self-evident. Inspired by a series of interviews with non-experts, they analysed data from Eurobarometer surveys to test the hypothesis that it is not risk perception that causes resistance to European citizens, but rather the lack of perceived benefits of GM foods. Some respondents see both pros and cons and could come to a decision based on a rational consideration. For others, it seems that the assumed benefits could greatly influence their final assessment of GM foods.

Since the late 1990s, various researchers have attempted to assess (changes in) public attitudes toward GM and GMOs in the Netherlands [e.g. Gutteling, 2002; Gutteling et al., 2006; Dijkstra, 2008]. As previously discussed, the 2010 Eurobarometer showed that the Dutch public is not enthusiastic about the use of GM in food. Those who oppose GM foods are generally concerned about how natural DNA modification is. Respondents indicated that they were worried about safety, and a lack of direct consumer benefits, associated with technological developments. At the same time, the Eurobarometer results showed a cautious level of public support for a new generation of GM applications, such as the introduction of wild apple genes into apples obtained by cisgenesis. Of the Dutch respondents, 48 percent suggested that this development should continue, while 46 percent disagreed [Eurobarometer, 2010, p. 94]. Applications in the medical sector or those focused on industrial production were less likely to be associated with societal resistance. Support for medical applications such as stem cell research was high in the Netherlands with 74 percent of participants in favour, provided that this type of research is subject to strict legislation [Eurobarometer, 2010, p. 117].

The influence of cultural orientation in relation to risk perception is central to the research of Kahan, Jenkins-Smith and Braman [2011]. They focused on cultural orientations, studying risk perceptions of "scientific facts" through the lens of cultural orientation. Cultural orientation can influence the extent to which one accepts certain facts regarding risks as reflecting reality [Kahan et al., 2009; Kahan, JenkinsSmith and Braman, 2011; Kahan et al., 2012]. This Cultural Cognition approach has been used to explain attitude polarisation in relation to climate change, nuclear power or nanotechnology in the United States. People's political orientation plays an important role in explaining the cultural orientations toward various topics, especially the Bi-partisan orientation as that is found in the United States. In contrast, the Dutch political landscape is formed by a multi-party system, with 21 political parties running for the elections in 2012. Thereby the Dutch political landscape is characterised by a consensus democracy, meaning that parties have to work together striving for a broad consensus in order to implement policies or make laws. Current GM and GMO legislation in the Netherlands originates within the European Commission, and GM implementation is strictly regulated and legislation is mainly focused on the safety aspects of GMOs and GM techniques [COGEM, 2016].

Another approach to understanding the public's attitude formation is the Gateway Belief Model [van der Linden et al., 2015]. The model suggests that public attitudes toward scientific issues such as climate change or GM food are driven by people's perception of the degree of scientific consensus on that issue [van der Linden et al., 2015; Dixon, 2016]. Although people are likely to rely on their political, cultural and value predispositions when they are processing new information, the Gateway 
Belief Model suggests that people's attitudes toward technologies are influenced by their perception of what scientists believe. Despite many ongoing discussions there still is no scientific [Hilbeck et al., 2015] or political consensus [COGEM, 2016] on the safety of GMOs in Europe.

Various authors have emphasised the importance of better understanding attitudes, not only toward GM but also toward other emerging technologies as nanotechnology [Cormick, 2009; Currall, 2009; Einsiedel and Goldenberg, 2004]. Research, mainly conducted in the U.S. and U.K., suggests that attitudes toward, for example, nanotechnology are determined by a range of factors as value differences [Gaskell et al., 2005], and religious beliefs [Scheufele and Lewenstein, 2005]. Earlier research showed that the Dutch, within Europe, are the most optimistic about the possibilities of science and technology to cure diseases [Dijkstra, 2008]. A segmentation study, conducted in 2011 [Cormick and Romanach, 2014], studied the role of different values in shaping attitudes toward biotechnology. Four segments were defined from values-based statements about science and technology in general, and its possible meaning in daily lives of people. Investigating support for GM applications within each of the four segments also provided insights into how these values aligned with attitudes toward different technologies. For example, the group with values most supportive of science and technology, who at the same time were not concerned about people "tampering with nature" as part of scientific and technological progress, had attitudes more in favour of biotechnology than other groups of people [Cormick and Romanach, 2014].

\section{GM information seeking behaviour}

Information Seeking models are not frequently used in the context of GM [Jennings, 2018]. This study provides the opportunity to study information seeking in this particular context. Scholars have identified individual risk information seeking behaviour as an important predictor of both an individual's propensity to accept a risk, or taking risk-mitigation actions in times of crisis. The motives for individual risk information seeking have been reported to be related to acquisition of knowledge, the reduction of risk or uncertainty associated with the risk, or to enable sharing or comparing information with important others [Griffin, Dunwoody and Neuwirth, 1999; Huurne and Gutteling, 2008]. The assumption is that individuals develop the intention to seek information in case of a perceived shortage in knowledge or understanding. This reasoning is also assumed in the Risk Information Seeking and Processing model (RISP) that identifies the gap between present knowledge and needed knowledge as the psychological motive 'information insufficiency' [Griffin, Dunwoody and Neuwirth, 1999; Yang, Aloe and Feeley, 2014]. Affective reactions, or emotions, may also stimulate risk information seeking [Griffin et al., 2008]. A relatively high frequency of GM information seeking could be an indication of a negative attitude toward GM.

The RISP assumes that the individual needs, or prefers, to hold a level of certainty on risk issues [Yang, Aloe and Feeley, 2014]. When uncertainty associated with the risk increases, the need for risk information develops and information seeking behaviour will occur. The model further suggests that uncertainty, trust in other people, and the information these people can potentially provide about a specific risk is interrelated. The individual's social network may influence the individual's 
need for information, and their information seeking behaviours. When important others are assumed to have specific knowledge about relevant issues, the individual is stimulated to seek information to be able to compare her or his skills and knowledge with that of others. Kahlor et al. [2006] confirmed that perceived peer pressure to be well informed about a risk represents a powerful predictor of information seeking.

Trust is an important element of the RISP model. According to Petts [2000], trust is one of the main influences of risk perceptions or attitudes, and the way people react to (risk) communication. "Trust is a psychological state comprising the intention to accept vulnerability based on positive expectations of the intentions or behaviour of another" [Rousseau et al., 1998, p. 395]. When granting trust to others, according to various scientific approaches, a number of perceived characteristics of the "object" of trust are relevant. For example, the extent to which an expert is perceived to be "competent" influences the extent to which they are trusted. "Fairness" generates trust if people perceive that all stakeholder perspectives are addressed. "Objectivity" refers to the individual or institution which is the focus of trust to provide non-biased information. Next there is "consistency": the behaviour of the one to be trusted and whether his or her expressions are predictable; "transparency" refers to openness and access to information; and "empathy" to a sense of good intentions in compiling information and a duty of care for others [Connor and Siegrist, 2010; Frewer, Scholderer and Bredahl, 2003; Petts, 2000; Poortinga and Pidgeon, 2005; Siegrist, Earle and Gutscher, 2003; Renn and Benighaus, 2013].

\section{Research questions}

Information seeking models have been infrequently applied in the context of GM. The research presented here is exploratory rather than confirmatory. Our research questions are: what is the relative predictive value of the independent variables: (1) Attitude toward science and technology, and (2) Trust in governance, Trust in GM organizations and Trust in GM regulations, on the dependent variables: (a) Attitude toward GM applications, and (b) GM Information seeking behaviour?

\section{Method}

Survey methodology was used to assess the attitudes of a representative sample of the Dutch population of 18 years and older. All data were collected between March 11, 2015 and April 3, 2015, by a commercial company NewCom Research, which specialises in opinion polling and is based in Amsterdam. Previous quantitative studies have suggested that online data collection is fast and allows the researcher to collect the opinion of many respondents in a relatively limited span of time. However, Dutch online samples tend to be skewed on demographics such as age group or educational level [personal communication project manager NewCom Research]. Older and less educated people tend to be underrepresented in online surveys. For that reason, we combined an online survey with telephone interviews, resulting in a total sample of $\mathrm{N}=1208$ (online $n=809$; telephone $\mathrm{n}=399$, with a response rate of $27 \%$ ). In the telephone interviews people who declined to cooperate were asked why they did so. The main reasons were: no interest in contributing $(66 \%)$, no time $(17 \%)$, the topic itself $(6 \%)$, or language issues $(3 \%)$.

Demographic characteristics of the final sample $(\mathrm{N}=1208)$ were compared to the Dutch national census data of 2015 [CBS, 2016]. The sample consisted of $46.4 \%$ men, 
while $49.1 \%$ of the Dutch population is male. The sample consisted of more respondents from 65 years and older than the Dutch population $(29.1 \%$ versus $21.8 \%)$ while younger age groups were slightly underrepresented $(7.5 \%$ versus $10.9 \%$ for 18 to 24 years, and $10.8 \%$ versus $15.3 \%$ for 25 to 34 years). We took no further action to weigh these differences in our statistical analysis because they were very small.

\section{Measurement instrument}

Items were selected for inclusion in the questionnaire based on previous findings from the literature as well as those specifically developed for this study. A supervisory committee, consisting of scholars and experts from various disciplines related to GM, reviewed the items to be included, and the questionnaire was tested online $(n=100)$ to improve the construction of the measures if required. The questionnaire consisted of four sections. A 5-point Likert-type scale accompanied the majority of the items. When applicable, a reliability analysis was performed to indicate internal consistency (Cronbach's alpha).

The first section of the questionnaire was designed to measure general attitudes and included six general statements derived from [Cormick and Romanach, 2014], which measured general attitudes toward science and technology. Originally, both authors included an item about people's faith, but this statement was replaced with the statement 'Science and technology make our lives easier and healthier'

[Eurobarometer, 2013]. All items were measured with 5-point scales ranging from 'completely disagree' to 'completely agree'. The item 'Children must be protected from all risks', correlated poorly with the other items. Therefore, a construct was created containing five items excluding this item. The final 5-item reliability analysis showed an acceptable internal consistency for the scale (Cronbach's $\alpha=.63$ ). ${ }^{1}$

The second section consisted of measures related to GM and GMOs information seeking behaviour. Respondents were asked about GM information seeking behaviour, that is, 'How frequently they would use which sources to get information about GM and GMOs' (4 items: Radio and TV, the internet, social media, print media), 5-point Likert scale from 'no, never' to 'yes, very often'; Cronbach's $\alpha=.76$ ).

In the third section, respondents' attitudes toward three specific GM applications (App) were measured in the context of the environmental, food and medical domains. Two items asked about each application. The applications were as follows: (App1) The use of detergents containing enzymes made by GM: 'I do not really mind what is in a detergent, if only it is affordable' and 'I buy detergents in the organic shop because than I am sure that there are no enzymes in it made using genetic modification'; (App2) The use of GM for the development of a new potato breed that is resistant to potato blight: 'Farmers need to decide if they are going to use this new-potato breed or not' and 'I think that potatoes of this new breed may be sold in the store as consumer potatoes'; (App3) the use of GM for making artificial insulin: 'I think it's important that enough and good medicines are available, even though they are made using genetic modification' and 'I only use medicines of which I know that they not have been made using genetic modification'. Each application was introduced by a short and

\footnotetext{
${ }^{1}$ Under certain conditions a Cronbach's alpha $>.60$ is acceptable [Loewenthal, 2004]. Such conditions apply to this measurement: we used an existing and modified scale in a new (Dutch) context, and we took a considerable sample $(\mathrm{N}=1208)$.
} 
neutral explanatory text. For all six items respondents could answer on a 5-point Likert scale ranging from 'completely disagree' to 'completely agree'. Recoding of the second and last item so that a higher score on an item would indicate a more positive attitude toward GM applications, and resulted in an acceptable Cronbach's alpha for the Attitude toward GM applications variable (Cronbach's $\alpha=.67$ ).

In the fourth section, six items related to governance issues based on previous findings of Gutteling et al. [2006] (5-point Likert scale from 'completely disagree' to 'completely agree; Cronbach's $\alpha=.73$ ). In addition, nine items asked about trust in various organizations related to GM and GMOs (5-point Likert scale from 'completely distrust to 'completely trust'; Cronbach's $\alpha=.79)$. Finally, trust in rules and regulations related to GM and GMOs was included (4 items, 5-point Likert scale ranging from 'completely disagree' to 'completely agree' Cronbach's $\alpha=.91$ ). See appendix A for all trust items.

Finally, demographic information was collected: Gender, Age group, Level of education, and Household size.

First, descriptive statistics are presented consisting of the Means and Standard Deviations (SDs) of the measured variables, as well as their inter-correlation (Table 1). Second, regression analysis will answer the primary question regarding the relative importance of the conceptual explanations for people's 'Attitude toward GM applications' or 'GM information seeking' preferences, that is the independent variables 'Attitude toward science and technology', and the three trust-measures: 'Trust in governance', 'Trust in organizations', and 'Trust in regulations'. Demographics were also included in this regression.

\section{Descriptive analysis}

To understand the relationships between the measures, we correlated each of the six variables with each other. The matrix shows multiple significant and positive correlations with p-values smaller than 0.01 .

Table 1. Correlations, Means and Standard Deviations for the six variables under study $(n=1208)$.

\begin{tabular}{|c|c|c|c|c|c|c|c|}
\hline & Mean & SD & 2 & 3 & 4 & 5 & 6 \\
\hline $\begin{array}{l}\text { 1. Attitude toward Science } \\
\text { and Technology }\end{array}$ & 3.12 & 0.65 & $.26^{* *}$ & $.20^{* *}$ & $.09^{* *}$ & $.20^{* *}$ & $.10^{* *}$ \\
\hline $\begin{array}{l}\text { 2. Attitude toward GM } \\
\text { Applications }\end{array}$ & 3.81 & 0.65 & & $-.16^{* *}$ & $.32^{* *}$ & $.33^{* *}$ & $.35^{* *}$ \\
\hline 3. GM Information Seeking & 1.82 & 0.73 & & & $-.12^{* *}$ & -.01 & $-.20^{* *}$ \\
\hline 4. Trust in Governance & 3.29 & 0.70 & & & & $.55^{* *}$ & $.57^{* *}$ \\
\hline 5. Trust in GM Organizations & 3.17 & 0.64 & & & & & $.50^{* *}$ \\
\hline 6. Trust in GM Regulations & 3.51 & 1.12 & & & & & \\
\hline
\end{tabular}

Table 4 in the appendix B presents the means and standard deviations for the six variables in Table 1, broken down by the four demographic variables: Gender, 
Educational level, Age, group, and Household size. On average the means in Table 1 indicate that the sample, representing the Dutch population, is reasonably positive toward GM applications (3.81), has a relatively high, to scale midpoint, level of trust in GM regulations (3.51), and has positive expectations toward governance issues (3.29) and GM organizations (3.17). The self-reported frequencies of seeking GM information in media and social sources is rather low (1.82). Attitudes toward science and technology are just above the scale midpoint (3.12).

The general 'Attitude toward science and technology' measure correlates significantly and positively with all other measures, i.e. 'Attitude toward GM applications', 'GM Information seeking', 'Trust in governance', 'Trust in organizations' and 'Trust in regulations'. In addition, 'Attitude toward GM applications' correlates significantly with all three Trust-measures as well, but negatively with the frequency of 'GM Information seeking'. Furthermore, the findings show that 'GM Information seeking' correlates weakly (negative) with the three Trust-measures.

\section{Advanced analysis}

Tables 2 and 3 present the data regarding the regression analysis, with the 'Attitude toward GM applications' and 'GM information seeking' as dependent variables. For both analyses hierarchical analysis was applied in which the first step, Model 1, of independent variables consisted of Demographics (Gender, Age group, Educational level, Household size). The second step, Model 2, added the Attitude toward science and technology to the equation. And the third and final step, Model 3 , inserted the three Trust-measures (Trust in governance, Trust in organizations, and Trust in regulations). Table 2 summarises the overall statistics of the analysis, and Table 3 presents the beta's and significance levels for each independent variables in each of the three steps of the analysis.

Table 2. Regression Analysis Model Summary: dependent variables Attitude toward GM Applications and GM Information Seeking.

\begin{tabular}{|lrrrrr|}
\hline $\begin{array}{l}\text { Model (M) } \\
\text { Attitude toward }\end{array}$ & $\mathrm{R}$ & $\mathrm{R}^{2}$ & $\mathrm{~F}$ change & $\mathrm{df}$ & \multicolumn{1}{c|}{ Sign. } \\
GM Applications & & & & & \\
M 1 & & & & & \\
M 2 & .073 & .005 & 1.317 & 4.974 & .262 \\
M 3 & .309 & .095 & 96.714 & 1.973 & $<.001$ \\
\hline GM Information & .458 & .210 & 46.860 & 3.970 & $<.001$ \\
Seeking & & & & & \\
M 1 & .261 & .064 & 17.852 & 4.974 & $<.001$ \\
M 2 & .271 & .069 & 5.554 & 1.973 & $<.05$ \\
M 3 & .339 & .108 & 15.191 & 3.970 & $<.001$ \\
\hline $\begin{array}{l}\text { Independents per Model: } \\
\text { Model 1: Demographics (Gender, Age group, Educational level, Household size) }\end{array}$ \\
$\begin{array}{l}\text { Model 2: Demographics, and Attitude toward Science and Technology } \\
\text { Model 3: Demographics, Attitude toward Science and Technology, and }\end{array}$ \\
\multicolumn{4}{l}{ Trust in Governance, Trust in Organizations, Trust in Regulations } \\
\hline
\end{tabular}

Table 2 indicates that the demographic variables (Model 1) predict 'GM Information seeking' significantly $(F(4,974)=17.852, p<.001)$, but not the 
'Attitude toward GM applications'. Adding the 'Attitude toward science and technology' significantly contributes to the explained variance of the 'Attitude toward GM applications' $(F(1,973)=96.714, p<.001)$ and 'GM Information seeking' $(F(1,973)=5.554, p=.019)$. With this addition the explained variance in the dependent variables increases to $9.5 \%$ and $6.9 \%$ respectively. The increase in explanatory power is higher for 'Attitude toward GM applications' (increase from $0.5 \%$ to $9.5 \%$ ), compared to 'GM Information seeking' (increase from $6.4 \%$ to $6.9 \%$ ). When the third set of independent variables is added, the 'Attitude toward GM applications' is even better explained $(21.0 \%)$. This addition is statistically significant $(F(3,970)=46.86, p<.001)$. The increase in the explained variance of 'GM Information seeking' is relatively small but significant (increase from $6.9 \%$ to $10.8 \%, F(3,970)=15.191, p<.001)$.

Table 3. Coefficients, $t$-values and significance levels for independent variables in the three analysed Models. Dependent variables: attitude toward GM Applications and GM Information Seeking.

\begin{tabular}{|c|c|c|c|c|c|c|}
\hline & \multicolumn{2}{|c|}{ Model 1} & \multicolumn{2}{|c|}{ Model 2} & \multicolumn{2}{|c|}{ Model 3} \\
\hline $\begin{array}{l}\text { Attitude toward } \\
\text { GM Applications }\end{array}$ & Beta & $\mathrm{t}$ & Beta & $\mathrm{t}$ & Beta & $\mathrm{t}$ \\
\hline Gender & .010 & -.299 & .057 & 1.763 & .40 & 1.331 \\
\hline Age group & .049 & 1.11 & .068 & $2.063 *$ & .058 & 1.865 \\
\hline Educational level & .015 & -.453 & -.101 & $-3.135 * *$ & -.037 & -1.219 \\
\hline Household size & .061 & 1.43 & .072 & 2.276 & .047 & 0.589 \\
\hline Att Science Technol. & & & .320 & $9.834^{* * *}$ & .234 & $7.410^{* * *}$ \\
\hline Trust in Governance & & & & & .112 & $2.960 * *$ \\
\hline Trust in Organizations & & & & & .102 & $2.816 * *$ \\
\hline Trust in Regulations & & & & & .201 & $5.422 * * *$ \\
\hline \multicolumn{6}{|l|}{ GM Information } & \\
\hline Gender & -.087 & $-2.701 *$ & -.070 & $-2.151 *$ & -.074 & $-2.312 *$ \\
\hline Age group & -.029 & -0.870 & -.025 & -0.730 & -.013 & -0.385 \\
\hline Educational level & .240 & $7.609 * * *$ & .219 & $6.697^{* * *}$ & .192 & $5.902 * * *$ \\
\hline Household size & -.038 & -1.189 & -.036 & -1.108 & -.017 & -0.549 \\
\hline Att Science Technol. & & & .078 & $2.357^{*}$ & .091 & $2.718^{* *}$ \\
\hline Trust in Governance & & & & & -.042 & -1.038 \\
\hline Trust in Organizations & & & & & .126 & $3.267^{* *}$ \\
\hline Trust in Regulations & & & & & -.220 & $-5.619 * * *$ \\
\hline \multicolumn{7}{|c|}{${ }^{*} p<.05,{ }^{* *} p<.01,{ }^{* * *} p<.001$} \\
\hline \multicolumn{7}{|c|}{ Independents per Model: } \\
\hline \multicolumn{7}{|c|}{ Model 1: Demographics (Gender, Age group, Educational level, Household size) } \\
\hline \multicolumn{7}{|c|}{ Model 2: Demographics, and Attitude toward Science and Technology } \\
\hline \multicolumn{7}{|c|}{ Model 3: Demographics, Attitude toward Science and Technology, and } \\
\hline Trust in Governanc & , Trust $i$ & Organizatio & ss, Trust & $n$ Regulat & & \\
\hline
\end{tabular}

Table 3 presents each of the individual independent variables and their predictive power (Beta and significance level) for the three separate models, for both the 'Attitude toward GM applications' and 'GM Information seeking'. For 'Attitude toward GM applications' the most complex model (model 3) has 'Attitude toward science and technology', 'Trust in governance', 'Trust in organizations' and 'Trust in regulations' as significant predictors. For 'GM Information seeking', 'Gender' and 
'Educational level' are significant predictors, however 'Trust in governance' does not predict 'GM Information seeking'. For 'Attitude toward GM applications' the 'Attitude toward science and technology' appears to be the most powerful predictor (Beta $=.234, p<.001)$. 'GM Information Seeking' is predicted best by 'Trust in regulations' (Beta $=.220, p<.001$ ).

Discussion and conclusions
The aim of this paper is to explore two hypothesized explanations for the public's Attitude toward GM applications and toward people's GM Information seeking preferences, namely the more general Attitude toward science and technology and the three Trust-measures. The data for this study were collected with a quantitative study, by means of a sample representative for the Dutch population of 18 years and older $(\mathrm{N}=1208)$. The data suggest that on average the Dutch population is somewhat positive toward GM applications, and has a relatively high level of trust in GM regulations, and a positive expectation toward governance issues and GM organizations. The frequency with which people seek GM information is low. Their attitude toward science and technology is just above the scale midpoint.

In Table 1 we see that the general 'Attitude toward science and technology' measure correlates significantly and positively with all other measures, that is with 'Attitude toward GM applications', 'GM Information seeking', 'Trust in governance', 'Trust in organizations' and 'Trust in regulations'. This is true also for 'Attitude toward GM applications', with the exception of 'GM Information seeking' where we see a significant but negative correlation. Furthermore, the findings show that 'GM Information seeking' correlates negatively with 'Attitude toward GM applications' and correlates negatively with 'Trust in governance' and 'Trust in regulations'.

These findings correspond to the RISP Model [Griffin, Dunwoody and Neuwirth, 1999; Yang, Aloe and Feeley, 2014] which means that a relatively high frequency of GM information seeking, would be an indication of a negative attitude toward GM, or a low level of trust in governance or in regulations. This seems to indicate that when people don't experience GM applications as an issue, their information seeking behaviour declines. Future studies might shed light on how this phenomenon might impact the overall communication with stakeholders and publics on GM and GMOs.

The Regression Analysis in Table 2 shows for both dependent variables Attitude toward GM applications and GM Information seeking that 'Attitude toward science and technology', 'Trust in organizations' and 'Trust in regulations' are significant predictors. For the first dependent variable Attitude toward GM applications 'Trust in Governance' is also a significant predictor. For the second dependent variable GM Information seeking these are 'Gender' and 'Educational level'. For Attitude toward GM applications the 'Attitude toward science and technology' appears to be the most powerful predictor. GM Information seeking is predicted best by 'Trust in regulations'. The explanatory power of the most complex model for both dependent variables is relatively low, respectively $21 \%$ for Attitudes toward GM applications, and $10.8 \%$ for GM Information seeking. We may conclude that the psychological variables are better predictors than demographics.

Most respondents apparently are not intrinsically in favour of or opposed against genetic modification or genetically modified organisms. Their attitude is more 
complex and is related to their general attitude toward science and technology, and to different aspects of trust. The research shows that respondents, regardless of their attitude toward science and technology, are not actively searching for information on GM and GMOs. This is also in line with previous studies that showed that most of the Dutch act passively toward biotechnology. Only when direct personal interests play a role people show a more active and engaging behaviour [Dijkstra et al., 2012; Gutteling et al., 2006]. Nevertheless, a positive attitude toward science and technology is also linked to a higher level of information seeking.

The analysis further shows that when the attitude of respondents toward science and technology is positive, this is associated with greater confidence in government and business and a steering role for both actors. The results also suggest that respondents themselves do not always think they are able to judge GM developments and want to delegate this - as a kind of watchdog task - to NGOs and other civil society organizations without direct interests in GM innovations as we have seen in the independent variables 'Trust in organizations' and 'Trust in regulations' which are significant predictors. The results support the idea that a more positive attitude toward science and technology is positively related to the attitude toward the three GM applications.

\section{Further research}

For the public it is becoming more difficult to indicate developments in the use of genetic modification. There is a lack of knowledge and people are not actively seeking for information as our study shows. At the same time, social media will pick up these new applications and the framing will be decisive for imaging and public perception. Discussions on social media usually do not focus on the technology itself, but on broader issues such as safety, health, economic interests or moral values [Blancke et al., 2015; Hanssen and De Vriend, 2011]. Therefore taking into account how people actually process and come across information can further enhance our insight in the formation of people's attitudes toward science and technology in general and toward genetic modification more specifically.

We have looked at the influence of information seeking behaviour on people's attitudes, but we did not take into account how the different GM applications are actually framed in current social media. Although the information seeking behaviour of our respondents is low with regard to the three GM applications, it is worthwhile to see what kind of information the Dutch people find within a range of media and social media sources. Is the information positively or negatively framed, and which stakeholder or expert is sending or discussing what information? With the emergence of various social media platforms, individuals share information and even take an active role in communication processes, at the same time changing the traditional roles of GM stakeholders and experts in their interactions with the public.

Acknowledgments We thank the supervisory committee of the COGEM for constructive comments during the process. We express our gratitude to Neil van der Veer MA and Steven Boekee MA from NewCom Research Amsterdam for their valuable input in 
compiling the measurement instrument and conducting the survey. Wieke Betten MSc from Vrije Universiteit Amsterdam for her valuable input in the discussions of the survey results. We also like to thank both anonymous referees for their valuable comments.

Funding

Appendix A. Scales used for the three Trust-measures
This paper is based on a study commissioned by the Netherlands Commission on Genetic Modification (COGEM, CGM 2015-05). We want to emphasise that the interpretation of the findings are our own.

Items constructing Trust in governance, Trust in organizations and Trust in regulations

Trust in governance (6 items)

I trust that the government is capable in its decision-making on genetic modification to take into account the interests of the public.

Civil society organizations (such as Greenpeace, WWF, Consumer, Animal Protection organizations or others) must have a large impact on decisions about genetic modification.

The government has sufficient knowledge about safety issues of genetic modification.

Civil society organizations have sufficient knowledge about safety issues of genetic modification.

I am not confident that businesses decisions on genetic modification sufficiently take into account the interests of the public.

I do not trust that civil society organizations decisions on genetic modification sufficiently take into account the interests of the public.

Trust in organizations (9 items)

Newspapers, magazines, radio or television that report on genetic modification.

Companies that make new products with the use of genetic modification.

Universities that do research into new possibilities of genetic modification.

Environmental protection organizations campaigning on genetic modification.

Consumer organizations that test genetically modified products.

General practitioners who advise on new medical tests and new medicines made with genetic modification. 
Government agencies that monitor the use of genetic modification.

Church leaders who indicate moral limits for the use of genetic modification.

Social media users who send messages about genetic modification.

Trust in regulations (4 items)

The current regulations in the Netherlands protect consumers against potential dangers or risks of genetically modified products.

There is law enforcement and supervision of companies and research institutes that work with genetic modification or with genetically modified organisms.

The current regulations in the Netherlands protect the personal data and the autonomy of patients.

There are procedures to ensure that everyone who doesn't want to buy genetically modified products can do this safely.

\section{Appendix B. \\ Segmentation of main variables by demographics}

Table 4. Means and (Standard Deviations) for the six variables under analysis, by gender, educational level, age group and household size.

\begin{tabular}{|c|c|c|c|c|c|c|}
\hline demographics & $\begin{array}{l}\text { Attitude } \\
\text { Science } \\
\text { Technology }\end{array}$ & $\begin{array}{c}\text { Attitude } \\
\text { toward GM } \\
\text { Applications }\end{array}$ & $\begin{array}{c}\text { GM } \\
\text { Information } \\
\text { Seeking }\end{array}$ & $\begin{array}{c}\text { Trust in } \\
\text { Governance }\end{array}$ & $\begin{array}{c}\text { Trust in } \\
\text { Organizations }\end{array}$ & $\begin{array}{c}\text { Trust in } \\
\text { Regulations }\end{array}$ \\
\hline \multicolumn{7}{|l|}{ Gender } \\
\hline$M(561)$ & $3.26(0.66)$ & $3.72(0.66)$ & $1.89(0.76)$ & $3.25(0,75)$ & $3.13(0.65)$ & 3.53 (1.15) \\
\hline F (647) & $3.00(0.62)$ & $3.66(0.65)$ & $1.76(0.70)$ & $3.31(0.66)$ & $3.19(0.61)$ & $3.50(1.08)$ \\
\hline \multicolumn{7}{|l|}{ Education level } \\
\hline Low (174) & $2.83(0.56)$ & $3.82(0.60)$ & $1.50(0.54)$ & $3.31(0.77)$ & $3.15(0.74)$ & $3.71(1.07)$ \\
\hline Med. (620) & $3.04(0.61)$ & $3.82(0.66)$ & $1.76(0.70)$ & $3.34(0.70)$ & $3.21(0.62)$ & $3.60(1.14)$ \\
\hline High (414) & $3.36(0.68)$ & $3.81(0.67)$ & $2.05(0.78)$ & $3.19(0.67)$ & $3.11(0.60)$ & $3.30(1.07)$ \\
\hline \multicolumn{7}{|l|}{ Age group } \\
\hline $18-24(90)$ & $3.34(0.62)$ & $3.87(0.62)$ & $1.97(0.90)$ & $3.37(0.59)$ & $3.24(0.50)$ & $3.55(0.87)$ \\
\hline 25-34 (131) & $3.19(0.63)$ & $3.80(0.70)$ & $1.87(0.81)$ & $3.24(0.74)$ & $3.19(0.62)$ & $3.34(1.18)$ \\
\hline 35-44 (183) & $3.10(0.60)$ & $3.77(0.66)$ & $1.85(0.76)$ & $3.23(0.66)$ & $3.08(0.61)$ & $3.48(1.08)$ \\
\hline $45-54(232)$ & $3.07(0.67)$ & $3.73(0.66)$ & $1.80(0.74)$ & $3.22(0.71)$ & $3.16(0.65)$ & $3.42(1.16)$ \\
\hline 55-64 (220) & $3.08(0.69)$ & $3.81(0.66)$ & $1.86(0.69)$ & $3.32(0.73)$ & $3.14(0.69)$ & $3.51(1.11)$ \\
\hline$>65$ (352) & $3.10(0.65)$ & $3.90(0.63)$ & $1.74(0.65)$ & $3.33(0.72)$ & $3.20(0.64)$ & 3.64 (1.13) \\
\hline \multicolumn{7}{|l|}{ Household size } \\
\hline $1(36)$ & $3.13(0.64)$ & $3.75(0.87)$ & $1.78(0.61)$ & $3.25(0.74)$ & $3.15(0.60)$ & 3.39 (1.09) \\
\hline $2-4(865)$ & $3.13(0.65)$ & $3.81(0.65)$ & $1.83(0.72)$ & $3.30(0.68)$ & $3.17(0.63)$ & $3.52(1.11)$ \\
\hline$>4(78)$ & $3.14(0.62)$ & $3.92(0.57)$ & $1.75(0.68)$ & $3.38(0.70)$ & $3.20(0.60)$ & $3.79(0.98)$ \\
\hline
\end{tabular}


Bauer, M. W., Kohring, M., Allansdottir, A. and Gutteling, J. M. (2001). 'The dramatisation of biotechnology in elite mass media'. In: Biotechnology 1996-2000. Ed. by M. W. Bauer and G. Gaskell. London, U.K.: Science Museum, pp. 35-52.

Bauer, M. W. and Gaskell, G., eds. (2001). Biotechnology 1996-2000. London, U.K.: Science Museum. URL: http://eprints.1se.ac.uk/8010/.

Blancke, S., Van Breusegem, F., De Jaeger, G., Braeckman, J. and Van Montagu, M. (2015). 'Fatal attraction: the intuitive appeal of GMO opposition'. Trends in Plant Science 20 (7), pp. 414-418. https : / doi .org/10.1016/j.tplants . 2015.03.011.

Border, P. and Dawson, M. (2016). Genome editing. POSTnote 541. London, U.K.: Parliamentary Office of Science and Technology (POST). URL: https: //researc hbriefings . parliament.uk/ResearchBriefing/Summary/POST-PN-0541.

Border, P. and Walker, J. (2017). New plant breeding techniques. POSTnote 548. London, U.K.: Parliamentary Office of Science and Technology (POST). URL: https://researchbriefings . parliament.uk/ResearchBriefing/Summar y/POST-PN-0548.

CBS (2016). Den Haag: Centraal Bureau voor de Statistiek. The Hague: Statistics Netherlands. URL: https://www.cbs.nl/en-gb/society/population.

COGEM (2016). Trend Analysis Biotechnology 2016. (CGM/160614-01). Bilthoven, Netherlands: Commission on Genetic Modification.

Connor, M. and Siegrist, M. (2010). 'Factors influencing people's acceptance of gene technology: the role of knowledge, health expectations, naturalness and social trust'. Science Communication 32 (4), pp. 514-538. https://doi.org/10.1177/1075547009358919.

Cooke, B. and Kothari, U. (2001). Participation: the New Tyranny? London, U.K.: Zed Books.

Cormick, C. (2009). 'Why do we need to know what the public thinks about nanotechnology?' NanoEthics 3 (2), pp. 167-173. https://doi.org/10.1007/s11569-009-0065-z.

Cormick, C. and Romanach, L. M. (2014). 'Segmentation studies provide insights to better understanding attitudes towards science and technology'. Trends in Biotechnology 32 (3), pp. 114-116. https://doi.org/10.1016/j.tibtech.2013.12.005.

Currall, S. C. (2009). 'Nanotechnology and society: new insights into public perceptions'. Nature Nanotechnology 4 (2), pp. 79-80. https://doi.org/10.1038/nnano.2008.423.

Cyranoski, D. (2010). 'Science and society: a pacific divide. A global survey of the scientific literate public reveals a pacific divide on key issues in science'. Nature 467 (7314), pp. 388-389. https://doi.org/10.1038/467388a.

Dijkstra, A. M. (2008). 'Of publics and science. How publics engage with biotechnology and genomics'. Ph.D. Thesis. Enschede, The Netherlands: University of Twente.

Dijkstra, A. M., Gutteling, J. M., Swart, J. A. A., Wieringa, N. F., Windt, H. J. van der and Seydel, E. R. (2012). 'Public participation in genomics research in the Netherlands: Validating a measurement scale'. Public Understanding of Science 21 (4), pp. 465-477. https://doi .org/10.1177/0963662510381036.

Dixon, G. (2016). 'Applying the Gateway Belief Model to Genetically Modified Food Perceptions: New Insights and Additional Questions'. Journal of Communication 66 (6), pp. 888-908. https://doi.org/10.1111/jcom. 12260.

Durant, J., Bauer, M. W. and Gaskell, G., eds. (1998). Biotechnology in the Public Sphere: A European Sourcebook. London, U.K.: Science Museum. 
Editorial (2016). 'Breaking out of the bubble'. Nature Biotechnology 34 (3), p. 213. https://doi.org/10.1038/nbt.3517.

Einsiedel, E., Allansdottir, A., Allum, N., Bauer, M., Berthomier, A., Chatjouli, A., De Cheveigné, S., Downey, R., Gutteling, J., Kohring, M., Leonarz, M., Manzoli, F., Olofsson, A., Prztestalski, A. and Rusanen, T. (2002). 'Brave new sheep - the clone named Dolly'. In: Biotechnology. The making of a global controversy. Ed. by M. W. Bauer and G. Gaskell. Cambridge, U.K.: Cambridge University Press, pp. 313-347.

Einsiedel, E. F. and Goldenberg, L. (2004). 'Dwarfing the social? Nanotechnology lessons from the biotechnology front'. Bulletin of Science, Technology E Society 24 (1), pp. 28-33. https://doi.org/10.1177/0270467604263110.

Eurobarometer (2010). Special Eurobarometer 341. Wave 73.1. Biotechnology. Brussels, Belgium: TNS Opinion \& Social on request of European Commission. URL: http://ec.europa.eu/public_opinion/archives/ebs/ebs_341_en.pdf.

- (2013). Special Eurobarometer 401. Responsible Research and Innovation (RRI), Science and Technology. Brussels, Belgium: TNS Opinion \& Social on request of European Commission. URL: http://ec . europa. eu/commfrontoffice/publico pinion/archives/ebs/ebs_401_en.pdf.

Frewer, L. J., Miles, S. and Marsh, R. (2002). 'The media and genetically modified foods: evidence in support of social amplification of risk'. Risk Analysis 22 (4), pp. 701-711. https://doi.org/10.1111/0272-4332.00062.

Frewer, L. J., Scholderer, J. and Bredahl, L. (2003). 'Communicating about the risks and benefits of genetically modified foods: the mediating role of trust'. Risk Analysis: An Official Publication of the Society for Risk Analysis 23 (6), pp. 1117-1133. PMID: 14641888.

Frewer, L. J., van der Lans, I. A., Fischer, A. R. H., Reinders, M. J., Menozzi, D., Zhang, X., van den Berg, I. and Zimmermann, K. L. (2013). 'Public perceptions of agri-food applications of genetic modification - a systematic review and meta-analysis'. Trends in Food Science E Technology 30 (2), pp. 142-152. https://doi.org/10.1016/j.tifs.2013.01.003.

Gaskell, G., Allum, N., Wagner, W., Kronberger, N., Torgersen, H., Hampel, J. and Bardes, J. (2004). 'GM foods and the misperception of risk perception'. Risk Analysis 24 (1), pp. 185-194. https://doi.org/10.1111/j.0272-4332.2004.00421.x.

Gaskell, G., Eyck, T. T., Jackson, J. and Veltri, G. (2005). 'Imagining nanotechnology: cultural support for technological innovation in Europe and the United States'. Public Understanding of Science 14 (1), pp. 81-90. https://doi.org/10.1177/0963662505048949.

Gaskell, G., Stares, S., Allansdottir, A., Allum, N., Castro, P., Esmer, Y., Fischler, C., Jackson, J., Kronberger, N., Hampel, J., Mejlgaard, N., Quintanilha, A., Rammer, A., Revuelta, G., Stoneman, P., Torgersen, H. and Wagner, W. (2010). Europeans and biotechnology in 2010: winds of change? A report to the European Commission's Directorate-General for Research. Brussels, Belgium: Directorate-General for Research, European Commission. URL: http: //ec . euro pa.eu/public_opinion/archives/ebs/ebs_341_winds_en.pdf.

Griffin, R. J., Dunwoody, S. and Neuwirth, K. (1999). 'Proposed model of the relationship of risk information seeking and processing to the development of preventive behaviors'. Environmental Research 80 (2), S230-S245. https://doi.org/10.1006/enrs.1998.3940. 
Griffin, R. J., Yang, Z., Huurne, E. ter, Boerner, F., Ortiz, S. and Dunwoody, S. (2008). 'After the Flood'. Science Communication 29 (3), pp. 285-315. https://doi.org/10.1177/1075547007312309.

Gutteling, J., Hanssen, L., Veer, N. van der and Seydel, E. (2006). ‘Trust in governance and the acceptance of genetically modified food in the Netherlands'. Public Understanding of Science 15 (1), pp. 103-112. https://doi.org/10.1177/0963662506057479.

Gutteling, J. M. (2002). 'Biotechnology in the Netherlands: controversy or consensus?' Public Understanding of Science 11 (2), pp. 131-142. https://doi.org/10.1088/0963-6625/11/2/303.

Hanssen, L. (2009). 'From transmission toward transaction. Design requirements for successful public participation in communication and governance of science and technology'. Ph.D. Thesis. Enschede, The Netherlands: University of Twente.

Hanssen, L. and De Vriend, H. (2011). De komst van sociale media: Een nieuwe dynamiek in het debat over biotechnologie? (CGM 2011-09). in Dutch. Bilthoven, The Netherlands: Netherlands Commission on Genetic Modification.

Hilbeck, A., Binimelis, R., Defarge, N., Steinbrecher, R., Székács, A., Wickson, F., Antoniou, M., Bereano, P. L., Clark, E. A., Hansen, M., Novotny, E., Heinemann, J., Meyer, H., Shiva, V. and Wynne, B. (2015). ‘No scientific consensus on GMO safety'. Environmental Sciences Europe 27 (4). https://doi.org/10.1186/s12302-014-0034-1.

Huurne, E. T. and Gutteling, J. (2008). 'Information needs and risk perception as predictors of risk information seeking'. Journal of Risk Research 11 (7), pp. 847-862. https://doi.org/10.1080/13669870701875750.

Irwin, A. (2014). 'From deficit to democracy (re-visited)'. Public Understanding of Science 23 (1), pp. 71-76. https://doi .org/10.1177/0963662513510646.

James, C. (2016). Global status of commercialized Biotech/GM crops: 2016. ISAAA Brief No. 52. Ithaca, NY, U.S.A.: ISAAA. URL: http://www. isaaa.org/resources/publications/briefs/52/.

Jennings, F. J. (2018). 'Where to turn? The influence of information source on belief and behavior'. Journal of Risk Research. Published online 9th January 2018, pp. 1-10. https://doi.org/10.1080/13669877.2017.1422788.

Kahan, D. M., Jenkins-Smith, H. and Braman, D. (2011). 'Cultural cognition of scientific consensus'. Journal of Risk Research 14 (2), pp. 147-174. https://doi.org/10.1080/13669877.2010.511246.

Kahan, D. M., Braman, D., Slovic, P., Gastil, J. and Cohen, G. (2009). 'Cultural cognition of the risks and benefits of nanotechnology'. Nature Nanotechnology 4 (2), pp. 87-90. https://doi.org/10.1038/nnano.2008.341.

Kahan, D. M., Peters, E., Wittlin, M., Slovic, P., Ouellette, L. L., Braman, D. and Mandel, G. (2012). 'The polarizing impact of science literacy and numeracy on perceived climate change risks'. Nature Climate Change 2, pp. 732-735. https://doi.org/10.1038/nclimate1547.

Kahlor, L., Dunwoody, S., Griffin, R. J. and Neuwirth, K. (2006). 'Seeking and processing information about impersonal risk'. Science Communication 28 (2), pp. 163-194. https://doi.org/10.1177/1075547006293916.

Kim, H. and Kim, J.-S. (2014). 'A guide to genome engineering with programmable nucleases'. Nature Reviews Genetics 15 (5), pp. 321-334.

https://doi.org/10.1038/nrg3686. 
Kronberger, N., Wagner, W. and Nagata, M. (2014). 'How natural is "more natural"? The role of method, type of transfer and familiarity for public perceptions of cisgenic and transgenic modification'. Science Communication 36 (1), pp. 106-130. https://doi.org/10.1177/1075547013500773.

Landrum, A. R., Hilgard, J., Lull, R. B., Akin, H. and Jamieson, K. H. (2018). 'Open and transparent research practices and public perceptions of the trustworthiness of agricultural biotechnology organizations'. Journal of Science Communication 17 (02), A04. https://doi .org/10.22323/2.17020204.

Leyser, O. (2014). 'Moving beyond the GM Debate'. PLoS Biology 12 (6), e1001887. https://doi.org/10.1371/journal.pbio.1001887.

Loewenthal, K. M. (2004). An introduction to psychological tests and scales. 2nd ed. Hove, U.K.: Psychology Press.

Lucht, J. (2015). 'Public acceptance of plant biotechnology and GM crops'. Viruses 7 (8), pp. 4254-4281. https://doi.org/10.3390/v7082819.

Marques, M. D., Critchley, C. R. and Walshe, J. (2015). 'Attitudes to genetically modified food over time: How trust in organizations and the media cycle predict support'. Public Understanding of Science 24 (5), pp. 601-618. https://doi.org/10.1177/0963662514542372. PMID: 25063421.

Nerlich, B. and McLeod, C. (2016). 'The dilemma of raising awareness "responsibly"'. EMBO reports 17 (4), pp. 481-485. https://doi.org/10.15252/embr.201541853.

Petts, J. I. (2000). 'Sustainable communication: implications for industry'. Process Safety and Environmental Protection 78 (4), pp. 270-278. https://doi.org/10.1205/095758200530781.

Poortinga, W. and Pidgeon, N. F. (2005). 'Trust in risk regulation: cause or consequence of the acceptability of GM food?' Risk Analysis 25 (1), pp. 199-209. https://doi.org/10.1111/j.0272-4332.2005.00579.x.

Post, S. and Maier, M. (2016). 'Stakeholders' rationales for representing uncertainties of biotechnological research'. Public Understanding of Science 25 (8), pp. 944-960. https://doi.org/10.1177/0963662516645039.

Reardon, S. (2016). 'Welcome to the CRISPR zoo. Birds and bees are just the beginning for a burgeoning technology'. Nature 531 (7593), pp. 160-163. https://doi.org/10.1038/531160a.

Renn, O. and Benighaus, C. (2013). 'Perception of technological risk: insights from research and lessons for risk communication and management'. Journal of Risk Research 16 (3-4), pp. 293-313. https://doi.org/10.1080/13669877.2012.729522.

Rousseau, D. M., Sitkin, S. B., Burt, R. S. and Camerer, C. (1998). 'Not so different after all: a cross-discipline view of trust'. Academy of Management Review 23 (3), pp. 393-404. https://doi.org/10.5465/amr.1998.926617.

Rousselière, D. and Rousselière, S. (2017). ‘Is biotechnology (more) acceptable when it enables a reduction in phytosanitary treatments? A European comparison of the acceptability of transgenesis and cisgenesis'. PLOS ONE 12 (9), e0183213. https://doi.org/10.1371/journal.pone.0183213.

Rutsaert, P., Regan, A., Pieniak, Z., McConnon, A., Moss, A., Wall, P. and Verbeke, W. (2013). 'The use of social media in food risk and benefit communication'. Trends in Food Science E Technology 30 (1), pp. 84-91. https://doi.org/10.1016/j.tifs.2012.10.006. 
Rutsaert, P., Pieniak, Z., Regan, A., McConnon, A., Kuttschreuter, M., Lores, M., Lozano, N., Guzzon, A., Santare, D. and Verbeke, W. (2014). 'Social media as a useful tool in food risk and benefit communication? A strategic orientation approach'. Food Policy 46, pp. 84-93.

https://doi.org/10.1016/j.foodpol.2014.02.003.

Sander, J. D. and Joung, J. K. (2014). ‘CRISPR-Cas systems for editing, regulating and targeting genomes'. Nature Biotechnology 32 (4), pp. 347-355. https://doi.org/10.1038/nbt.2842.

Scheufele, D. A. and Lewenstein, B. V. (2005). 'The public and nanotechnology: how citizens make sense of emerging technologies'. Journal of Nanoparticle Research 7 (6), pp. 659-667. https://doi.org/10.1007/s11051-005-7526-2.

Siegrist, M., Earle, T. C. and Gutscher, H. (2003). 'Test of a trust and confidence model in the applied context of electromagnetic field (EMF) risks'. Risk Analysis 23 (4), pp. 705-716. https://doi.org/10.1111/1539-6924.00349.

van der Linden, S. L., Leiserowitz, A. A., Feinberg, G. D. and Maibach, E. W. (2015). 'The Scientific Consensus on Climate Change as a Gateway Belief: Experimental Evidence'. PLOS ONE 10 (2), e0118489. https://doi.org/10.1371/journal.pone.0118489.

Van der Veer, N., Gutteling, J. M., Hanssen, L. and Seydel, E. (2001). 'Wiens woord men gelooft diens brood men eet. De rol van publieksvertrouwen bij acceptatie van genvoedsel'. Tijdschrift voor Communicatiewetenschap 30 (4). in Dutch, pp. 315-330.

Van Dijck, J., Poell, T. and De Waal, M. (2016). De Platformsamenleving. De strijd om publieke waarden in een online wereld. in Dutch. Amsterdam, The Netherlands: Amsterdam University Press.

Vugt, M. V. (2009). 'Averting the tragedy of the commons. Using social psychological science to protect the environment'. Current Directions in Psychological Science 18 (3), pp. 169-173. https://doi.org/10.1111/j.1467-8721.2009.01630.x.

Yang, Z. J., Aloe, A. M. and Feeley, T. H. (2014). 'Risk information seeking and processing model: a meta-analysis'. Journal of Communication 64 (1), pp. 20-41. https://doi.org/10.1111/jcom.12071.

\section{Authors}

Lucien Hanssen PhD is director of Deining Societal Communication. The Dutch consultancy Deining focuses on societal implications of technological innovations and environmental challenges. Deining offers development of methods and strategies for dealing with wicked problems, next to facilitation and board advice, he is engaged in various academic research projects of the Universities of Nijmegen and Twente. A particular focus of his research and consultancy relates to developing interdisciplinary activities between the social and natural sciences. E-mail: 1.hanssen@fo.nl.

Anne M. Dijkstra PhD is an Assistant Professor at the University of Twente in the Netherlands. She studies the relationship between Science, Technology and Society from a communication perspective. Her research focuses on science and risk communication, risk governance and public participation regarding emerging technologies such as genomics, nanotechnologies and human enhancement. In 2013 she was a visiting researcher at Newcastle University and Durham University. She is currently involved in two European projects on Responsible Research and Innovation. E-mail: a.m.dijkstra@utwente.nl. 
Susanne Sleenhoff $\mathrm{PhD}$ is project leader at the Valorisation Centre of the Delft University of Technology in the Netherlands. At this tech transfer office she supports scientists and engineers with creating impact for their work. She studied the value of emotions for public engagement with the bio-based economy. Her research focuses on the impact and use of 2D and 3D visuals for generating dialogue and impact. She is currently involved with the programming for the International Festival of Technology. E-mail: s.sleenhoff@tudelft.nl.

Lynn J. Frewer is Professor of Food and Society and Newcastle University in the U.K., (since 2011). She studied at the Bristol University, U.K., (where she was awarded a PhD in Psychology), UCL in the U.K. (MSc in Ergonomics) and the University of Leeds, U.K. (PhD in applied psychology). She was appointed as Professor of Food Safety and Consumer Behaviour at Wageningen University (2002-2011). Lynn has research interests focused on different aspects of food, food production and society. E-mail: lynn.frewer@newcastle.ac.uk.

Jan M. Gutteling PhD is an Associate Professor of Crisis and Risk Communication at the University of Twente in the Netherlands, as well as an independent researcher and consultant. His expertise focuses on the understanding of risk perception and the application of this understanding in crisis and risk communication. Studies are primarily quantitative and empirical, and aimed (1) to develop social psychological models of risk perception, or (2) aimed to establish experimentally how and under which circumstances risk communication and information influence risk perception and risk-related and resilient behaviour. E-mail: j.m.gutteling@utwente.nl.

\section{How to cite}

Hanssen, L., Dijkstra, A. M., Sleenhoff, S., Frewer, L. J. and Gutteling, J. M. (2018). 'Revisiting public debate on Genetic Modification and Genetically Modified Organisms. Explanations for contemporary Dutch public attitudes'. JCOM 17 (04), A01. https:/ /doi.org/10.22323/2.17040201. 